\title{
APC and chromosome instability in colorectal cancer
}

\author{
C. M. Cabrera and M. A. López-Nevot ${ }^{1}$ \\ Services of Pathology and ${ }^{I}$ Clinical Analysis. Hospital Universitario Virgen de las Nieves. Granada, Spain
}

\begin{abstract}
Colon cancer is a common disease that can be sporadic or familial. An inactivated adenomatous polyposis coli (APC) suppressor gene is found in over $80 \%$ of colorectal tumors, this being an early alteration in the development of adenomatous polyps. APC function is not only critical for tumor initiation and progression, and chromosome instability (CIN) is another characteristic dependent at least partly on APC mutations.
\end{abstract}

Key words: Colorectal cancer. APC. Chromosome instability.

Cabrera CM, López-Nevot MA. APC and chromosome instability in colorectal cancer. Rev Esp Enferm Dig 2005; 97: 738-743.

\section{INTRODUCTION}

The colon is organized into cell compartments called crypts. It is widely believed that adenomas develop from normal stem cells located at the bases of normal crypts (1). The progeny of stem cells migrate up the crypt and continue to divide until they reach its mid portion. Subsequently, migrating epithelial cells stop dividing and differentiate to mature cells instead. When differentiated cells reach the top of the crypt, they undergo apoptosis and are engulfed by stromal cells or shed into the lumen. This journey from the crypt's base to the apex lasts 3-6 days $(2,3)$. Usually, the birth rate of colonic epithelial

Recibido: 11-02-05.

Aceptado: 10-05-05.

Correspondencia: Carmen M. Cabrera. Servicio de Anatomía Patológica. Hospital Universitario Virgen de las Nieves. $4^{\mathrm{a}}$ planta, edificio de Gobierno. Avenida Fuerzas Armadas, 2. 18014 Granada. Fax: 958092 438. email: mcabrm@fundacionhvn.org cells precisely equals the loss rate from the crypt apex. When the birth/loss ratio increases a tumor results.

Colorectal tumors progress through a series of clinical and histopathological stages ranging from dysplastic crypts through small benign tumors to malignant cancers. This progression is the result of a series of genetic changes that involve activation of oncogenes and inactivation of tumor suppressor genes (4). In colorectal cancer, chromosomal instability (CIN) is the major form of genetic instability (5). Mutation of the APC gene is the earliest event yet identified in sporadic colorectal tumorigenesis, and it is estimated that $>85 \%$ of colorectal tumors have somatic mutations of the APC gene (5).

\section{APC STRUCTURE AND FUNCTION}

The APC gene encodes a large multidomain protein that has many different sites for interaction with other proteins. It is present in a variety of epithelial tissues, usually in cells that are post-mitotic (6). Immunohistochemical studies show that APC is often diffusely distributed in the cytoplasm, although it can sometimes be found in the apical or lateral regions of epithelial cells (6). Studies indicate that APC participates in a variety of cellular functions including proliferation, differentiation, apoptosis, adhesion, migration, and chromosomal segregation (7).

Figure 1 shows the various domains within APC that interact with other proteins. The armadillo repeat at the $\mathrm{N}$-terminal portion binds to the B56 regulatory subunit of protein phosphatase $2 \mathrm{~A}$ and APC-stimulated guanine exchange factor (8). These two proteins may be involved in the Wingless (Wnt) signaling pathway, of which APC is a component $(8,9)$. Another important domain includes three 15 -amino acid repeats that bind $\beta$-catenin, and seven 20-amino acid repeats that are required for the downregulation of $\beta$-catenin $(10,11)$. Sites in APC have also 


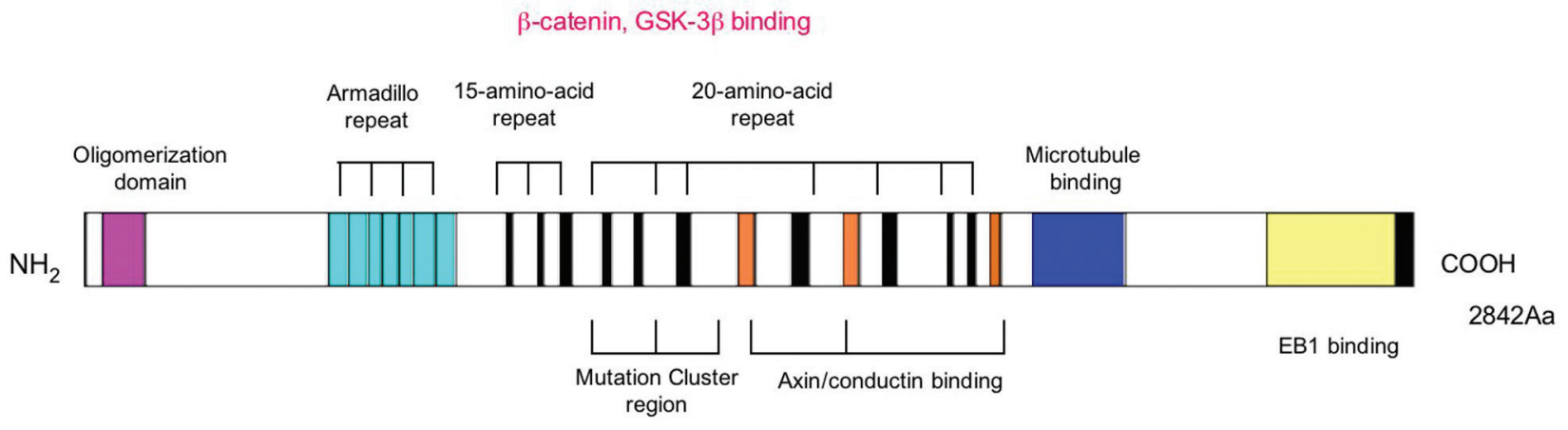

Fig. 1.- The different domains of the APC protein. Conserved regions, such as Armadillo repeats, and regions that interact with other proteins, including tubulin, the microtubule-associated protein EB1, $\beta$-catenin, and axin/conductin, are shown.

Dominios de la proteína APC. Presenta regiones conservadas como las repeticiones Armadillo; y regiones que interaccionan con otras proteínas, incluyendo tubulina, la proteína EB1 asociada a microtúbulos, $\beta$-catenina, y axina/conductina.

been identified that interact with axin and conductin $(12,13)$, two inhibitory proteins of the Wnt signaling pathway. The $\mathrm{C}$ terminal portion of the protein is involved in binding to microtubules and tubulin-binding protein EB1 (14).

Mutational analysis of the APC gene indicates that the majority of germline mutations found in patients with familial adenomatous polyposis (FAP) are nonsense mutations, leading to the formation of a truncated protein. More than $60 \%$ of APC mutations are found in the central region (between codons 1284 and 1580) of the protein, which is called the mutation cluster region (MCR)

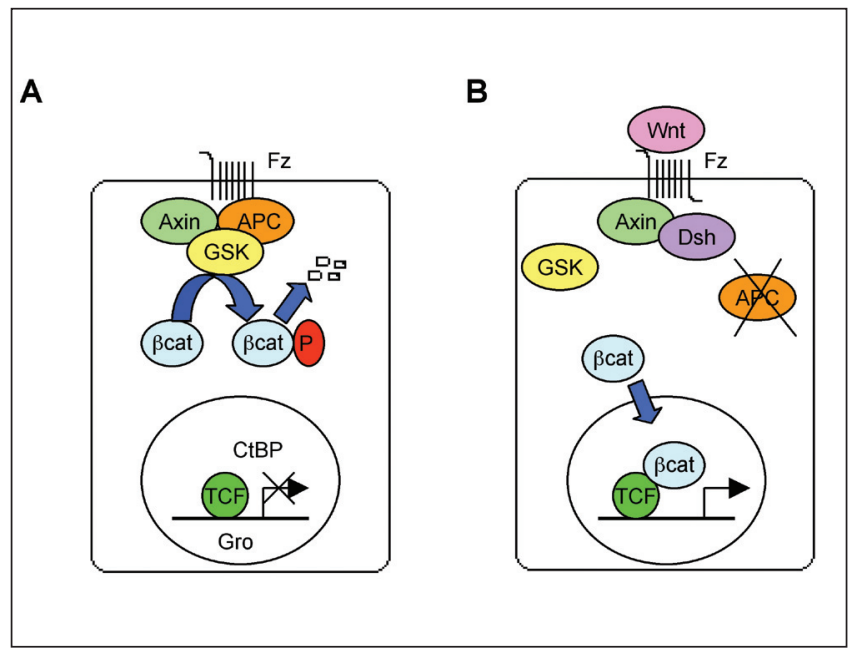

Fig. 2.- The signaling pathways in the absence $(A)$ and the presence $(B)$ of the Wnt ligand. Fz, frizzled receptor; Dsh, dishevelled protein. Upon the binding of the Wnt ligand to its receptor Fz, the dishevelled protein is activated.

Rutas de señalización en presencia (A) y ausencia (B) de un ligando Wnt. Fz, receptor frizzled; Dsh, proteína dishevelled. La unión del ligando Wnt a su receptor $F z$, activa a la proteína dishevelled.
(15). The MCR region coincides with a region in APC that is important for the down-regulation of $\beta$-catenin, which suggests that this function is important for the pathogenesis of colorectal cancer. Subsequent studies demonstrated that APC and $\beta$-catenin are important parts of the Wnt signaling pathway (Fig. 2). The greatest progress in understanding the function of APC has been made in studying its interaction with glycogen synthase kinase (GSK)-3 $\beta$ and $\beta$-catenin, both being essential components of the Wnt signaling pathway (5). GSK-3 $\beta$ makes up complexes with APC, $\beta$-catenin, and axin, and then phosphorylates $\beta$-catenin. Phosphorylation targets $\beta$-catenin for degradation via an ubiquitin-mediated proteasomal pathway (16). Truncation of APC results in the disruption of complex formation and ultimately increased cytoplasmic levels of $\beta$-catenin. Free $\beta$-catenin is translocated to the nucleus, where it interacts with T-cell factors (TCFs) (Fig. 2). TCF-4 is the predominant member of this family of transcription factors in colonic epithelial cells, and activation of this pathway upregulates oncogenes c-Myc and cyclin D1 $(17,18)$. These findings suggest that $\beta$-catenin upregulates TCF-responsive genes critical for the proliferation and transformation of colonic epithelial cells. In this context, it is noteworthy that a gain-of-function mutation in the $\beta$-catenin gene has been identified in as many as $50 \%$ of colon tumors with an intact APC (19).

\section{APC AND CHROMOSOME INSTABILITY (CIN)}

Recent studies have shown that the $\mathrm{C}$ terminus of the APC protein is involved in maintaining chromosome stability during mitosis $(20,21)$. APC is localized in the kinetochore of metaphase chromosomes, and this localization is likely dependent on the interaction between 
APC and EB1. Accordingly, APC-mutant cells have an abundance of spindle microtubules that fail to connect to the kinetochore and are characterized by CIN (22). In the mouse model that involves a mutation at codon 1628 of the APC gene ( $\mathrm{APC}^{1638}$ ), this mutation truncates the C-terminal portion of APC responsible for CIN-related functions but retains the $\beta$-catenin regulatory domain (20). Consequently, embryonic stem (ES) cells isolated from homozygous $\mathrm{APC}^{1638 \mathrm{~T}}$ animals were CIN (20). However, the corresponding mice were viable and tumor-free. In contrast, the classic mouse model $\mathrm{APC}^{\mathrm{Min}}$ that carries a nonsense mutation at codon 850 truncated the region required to regulate $\beta$-catenin. The heterozygous $\mathrm{APC}^{+/ \mathrm{Min}}$ animals develop numerous adenomas in their intestinal tract (23). These observations underscore the importance of the selective advantage provided by the loss of $\beta$ catenin control in tumor formation, and argue against the ability of chromosomal instability to initiate the oncogenic process.

\section{CHROMOSOME INSTABILITY IN TUMOR INITIATION}

Colorectal cancer is one of the best understood systems for the study of the genetics of cancer progression. Two types of genetic instability have been identified, with chromosomal instability predominating $(24,25)$.

The molecular basis for CIN is just beginning to be explored (26). A large number of gene alterations can give rise to CIN in Saccharomyces cerevisiae $(27,28)$. These genes include those involved in chromosome condensation, sister-chromatid cohesion, kinetochore structure and function, and microtubule formation and dynamics as well as checkpoints that monitor the progress of the cell cycle. To date, the only genes implicated in aneuploidy in human tumor cells are those of the latter class. Heterozygous mutations in the mitotic spindle checkpoint gene hBUB1 were detected in a small portion of colorectal tumors with the CIN phenotype (29). Mutations in hBUB1 can function in a dominant-negative manner in both mouse and human cells, conferring an abnormal spindle checkpoint when expressed exogenously $(29,30)$. These results also confirmed cell-fusion studies that indicate that the CIN phenotype has a dominant quality and it might only require a single mutational "hit" to produce CIN (31).

Most APC mutations observed in patients lead to the truncation of the encoded protein, with loss of the carboxyl-terminal sequences that interact with microtubules (20). However, some well characterized human colon cancer cell lines with APC mutations have chromosome complements that have remained perfectly stable and invariable over thousands of cell divisions in vitro $(31,32)$. Therefore, it is unlikely that APC inactivation itself triggers CIN in human colorectal cancer.

\section{CONCLUSION}

The fact that genomic defects in so many genes can lead to CIN, at least in yeast, suggests a heterogeneous basis for CIN in tumors, with many genes each playing a role in a small proportion of cases. Accordingly, CIN may be so common in tumors precisely because there are so many genes that, when mutated, can lead to this phenotype. Therefore, in colorectal tumors, chromosomal instability as observed is not only originated by APC mutations, and probably other mitotic checkpoint genes can be involved in this process.

\section{REFERENCES}

1. Bach SP, Renehan AG, Potten CS. Stem cells: the intestinal stem cell as a paradigm. Carcinogenesis 2000; 21: 469-76.

2. Lipkin M, Bell B, Shelrock P. Generation time of epithelial cells in the human colon. Nature 1962; 195: 175-7.

3. Shorter RG, Moertel CG, Titus JL. Cell kinetics in the jejunum and rectum of man. Am J Dig Dis 1964; 9: 760-3.

4. Cruz-Bustillo Clarens D. Molecular genetics of colorectal cancer. Rev Esp Enferm Dig 2004; 96: 48-59.

5. Chung DC. The genetic basis of colorectal cancer: insights into critical pathways of tumorigenesis. Gastroenterology 2000; 119: 854-65.

6. Midgley CA, White S, Howitt R, Save V, Dunlop MG, Hall PA, et al APC expression in normal human tissues. J Pathol 1997; 181: 426-33.

7. van Es JH, Giles RH, Clevers HC. The many faces of the tumor suppressor gene APC. Exp Cell Res 2001; 264: 126-34.

8. Seeling JM, Miller JR, Gil R, Moon RT, White RT, Virshup DM. Regulation of beta-catenin signaling by the B56 subunit of protein phosphatase 2A. Science 1999; 283: 2089-91.

9. Kawasaki Y, Senda T, Ishidate T, Koyama R, Morishita T, Iwayama $\mathrm{Y}$, et al. Asef, a link between the tumor suppressor APC and G-protein signaling. Science 2000; 289: 1194-7.

10. Rubinfeld B, Souza B, Albert I, Muller O, Chamberlain SH, Masiarz FR, et al. Association of the APC gene product with beta-catenin. Science 1993; 262: 1731-4.

11. Su LK, Vogelstein B, Kinzler KW. Association of the APC tumor suppressor protein with catenins. Science 1993; 262: 1734-7.

12. Behrens J, Jerchow BA, Wurtele M, Grimm J, Asbrand C, Wirtz R, et al. Functional interaction of an axin homolog, conductin, with betacatenin, APC, and GSK3 beta. Science 1998; 280: 596-9.

13. Kishida S, Yamamoto H, Ikeda S, Kishida M, Sakamoto I, Koyama S, et al. Axin, a negative regulator of the Wnt signaling pathway, directly interacts with adenomatous polyposis coli and regulates the stabilization of beta-catenin. J Biol Chem 1998; 273: 10823-6.

14. Su LK, Burrell M, Hill DE, Gyuris J, Brent R, Wiltshire R, et al. APC binds to the novel protein EB1. Cancer Res 1995; 55: 29727.

15. Miyoshi Y, Nagase H, Ando H, Horii A, Ichii S, Nakatsuru S, et al. Somatic mutations of the APC gene in colorectal tumors: mutation cluster region in the APC gene. Hum Mol Genet 1992; 1: 229-33.

16. Rubinfeld B, Albert I, Porfiri E, Fiol C, Munemitsu S, Polakis P. Binding of GSK $3 \beta$ to the APC- $\beta$-catenin complex and regulation of complex assembly. Science 1996; 272: 1023-6.

17. He TC, Sparks AB, Rago C, Hermeking H, Zawel L, da Costa LT, et al. Identification of c-myc as a target of the APC pathway. Science 1998; 281: 1509-12.

18. Tetsu O, McCormick F. Beta-catenin regulates expression of cyclin D1 in colon carcinoma cells. Nature 1999; 398: 422-6.

19. Sparks AB, Morin PJ, Vogelstein B, Kinzler KW. Mutational analysis of the APC/ $\beta$-catenin/TCF-pathway in colorectal cancer. Cancer Res 1998; 58: 1130-4.

20. Fodde R, Kuipers J, Rosenberg C, Smits R, Kielman M, Gaspar C, et al. Mutations in the APC tumor suppressor gene cause chromosomal instability. Nat Cell Biol 2001; 3: 433-8. 
21. Kaplan KB, Burds AA, Swedlow JR, Bekir SS, Sorger PK, Nathke IS. A role for the Adenomatous polyposis coli protein in chromosome segregation. Nat Cell Biol 2001; 3: 429-32.

22. Green RA, Kaplan KB. Chromosome instability in colorectal tumor cells is associated with defects in microtubule plus-end attachments caused by a dominant mutation in APC. J Cell Biol 2003; 163: 949-61.

23. Su LK, Kinzler KW, Vogelstein B, Preisinger AC, Moser AR, Luongo $\mathrm{C}$, et al. Multiple intestinal neoplasia caused by a mutation in the murine homolog of the APC gene. Science 1992; 256: 668-70.

24. Lengauer C, Kinzler KW, Vogelstein B. Genetic instabilities in human cancers. Nature 1998; 396: 643-9.

25. Sen S. Aneuploidy and cancer. Curr Opin Oncol 2000; 12: 82-8.

26. Maser RS, DePinho RA. Connecting chromosomes, crisis, and cancer. Science 2002; 297: 565-9.

27. Kolodner RD, Putnam CD, Myung K. Maintenance of genome sta- bility in Saccharomyces cerevisiae. Science 2002; 297: 552-7.

28. Nasmyth K. Segregating sister genomes: the molecular biology of chromosome separation. Science 2002; 297: 559-65.

29. Cahill DP, Lengauer C, Yu J, Riggins GJ, Willson JKV, Markowitz $\mathrm{SD}$, et al. Mutations of mitotic checkpoint genes in human cancers. Nature 1998; 392: 300-3.

30. Bardelli A, Cahill DP, Lederer G, Speicher MR, Kinzler KW, Vogelstein B, et al. Carcinogen-specific induction of genetic instability. Proc Natl Acad Sci USA 2001; 98: 5770-5.

31. Lengauer C, Kinzler KW, Vogelstein B. Genetic instability in colorectal cancer. Nature 1997; 386: 623-7.

32. Abdel-Rahman WM, Katsura K, Rens W, Gorman PA, Sherr D, Bicknell D, et al. Spectral karyotyping suggests additional subsets of colorectal cancers characterized by pattern of chromosome rearrangement. Proc Natl Acad Sci USA 2001; 98: 2538-43. 